\title{
3D Geological Model of the Eastern Haouz Region (Morocco): Hydrogeological Implications
}

\author{
Rochdane Samia \\ Cadi Ayyad University, Marrakesh, Morocco, Center of Studies on \\ Geography and Spatial Planning (CEGOT), Geography Department, Faculty \\ of Arts, University of Porto, Portugal, Mohammed VI Polytechnic \\ University (UM6P) \\ El Mandour Abdennabi \\ Cadi Ayyad University, Marrakesh, Morocco \\ Daafi Youssef \\ Cadi Ayyad University, Marrakesh, Morocco \\ Mohammed VI Polytechnic University (UM6P) \\ Baudron Paul \\ Polytechnique Montréal, Canada \\ Chkara Ismail \\ Abdelmalek Essaadi University, Tétouan, Morocco \\ Teixeira José \\ Gomes Alberto
}

Center of Studies on Geography and Spatial Planning (CEGOT), Geography

Department, Faculty of Arts, University of Porto, Portugal

Doi: 10.19044/esj.2018.v14n24p53～URL:http://dx.doi.org/10.19044/esj.2018.v14n24p53

\begin{abstract}
The Eastern Haouz in Morroco is an agricultural region in full demographic, economic, and touristic expansion. To meet the increasingly growing demand of water, this paper focuses on the geological modelling of the basin geometry and on understanding the groundwater circulation. This work presents a geological model of the study area by integrating geological and hydrogeological aspects. It aims to describe a natural complex object by simplifying it to a conceptual and a numerical model. This is aimed at providing a better understanding of the geometry and the characteristics of the reservoir. The cross-sections and the treatment of deep boreholes data confirmed the results of geological modeling. It, however, shows that the region is synclinal and surrounded by two outcrops: the Jebilet and the High Atlas mountains. At the South of the plain, the large thickness of the cover gives a good accumulation of water and ensures the reservoir supply. The rise
\end{abstract}


of the basement in the north of the plain imposes a dividing line with two groundwater flow directions.

Keywords: Geology, geometry, 3D representation, hydrogeology, Haouz basin

\section{Introduction}

In arid and semi-arid regions, water needs for human and agricultural needs are generally covered by groundwater (Carneiro et al., 2010). Because of its location, harsh weather conditions (erratic rainfall), the insufficient intake in dams whose water is used for irrigation, and overexploitation of aquifers, Morocco is designated as a country with limited water potential.

The assessment and knowledge of water resources is essential for making appropriate decision and a sustainable management of this resource. For a proper management of groundwater, it must be based first on a study of geological formations (Frind et al., 2002). A thorough understanding of the geological structure is essential for the development of strategies for the protection of groundwater. Moreover, the presence of heterogeneities in geological records is generally associated with changes in facies that have a role in changing the hydrodynamic conditions of groundwater (Cabello et al., 2007). Therefore, a precise knowledge of the geology, geometrical aspects, and spatial relationships between the geological formations and the presence of tectonics that deform them is essential (Gámez, 2007). The analysis and representation of the geology for hydrogeological numerical models are often based on 2D. However, 3D analysis is needed to get a better understanding of complex geological systems (Jiménez-Martinez et al., 2011).

Geological modeling helps to better understand the subsoil and the groundwater flow pattern. 3D modeling of geological layers provides very important representation in several disciplines of geology. However, there are many areas where the use of modeling and 3D visualization is promising as scientific knowledge (Aug, 2004). In addition, there are many works that we can cite in hydrogeology (Dessargues, 2000; Kaufmann \& Martin, 2008; Gallerini \& De Donatis, 2009; El Yaouti et al., 2009; Bouazza et al., 2013; Mathers et al., 2014), exploitation of mineral and petroleum resources (Rziki, 2012; Daafi, 2014), Environment (El Bouqdaoui, 2009), mineralogy (Wang et al., 2015), and in risk management (Chkara, 2011). In geological mapping, among others, the use of computers allows a wide dissemination of information and sharing to all stakeholders of geosciences.

The purpose of this research is to establish the $3 \mathrm{D}$ model of the subsurface and the relationship between the cover and the basement that forms the eastern Haouz in Morocco. This can be achieved by combining information from a hundred deep wells and boreholes provided by the 
hydrological basin agency of Marrakesh and Digital Terrain Model. The Eastern Haouz (Western Morocco), located in a semi-arid area, constitutes a significant fraction of water resources of the Haouz basin. Here, we can observe high population densities and intensive farming. This is an area where the water demand is increasingly important. The 3D geological model established, provides a common initial framework for hydrogeological applications.

\section{The Eastern Haouz Area}

\section{Local Picture}

The study area which covers about $2800 \mathrm{~km}^{2}$ is part of Eastern Haouz and Tassaout areas. Thus, it is located about $60 \mathrm{~km}$ eastward Marrakesh city (Figure 1). It is part of the Western Moroccan Meseta and extends to the eastwest direction between the mountain ranges of the High Atlas in the south, and the Hercynian Jebilet in the north (Figure 1). The area is drained by the Tassaout and Lakhdar Rivers in the eastern part. Both of these rivers are fed by the High Atlas Mountains, join together downstream, and then flows northwards. Rdat River in the western part flows westwards.

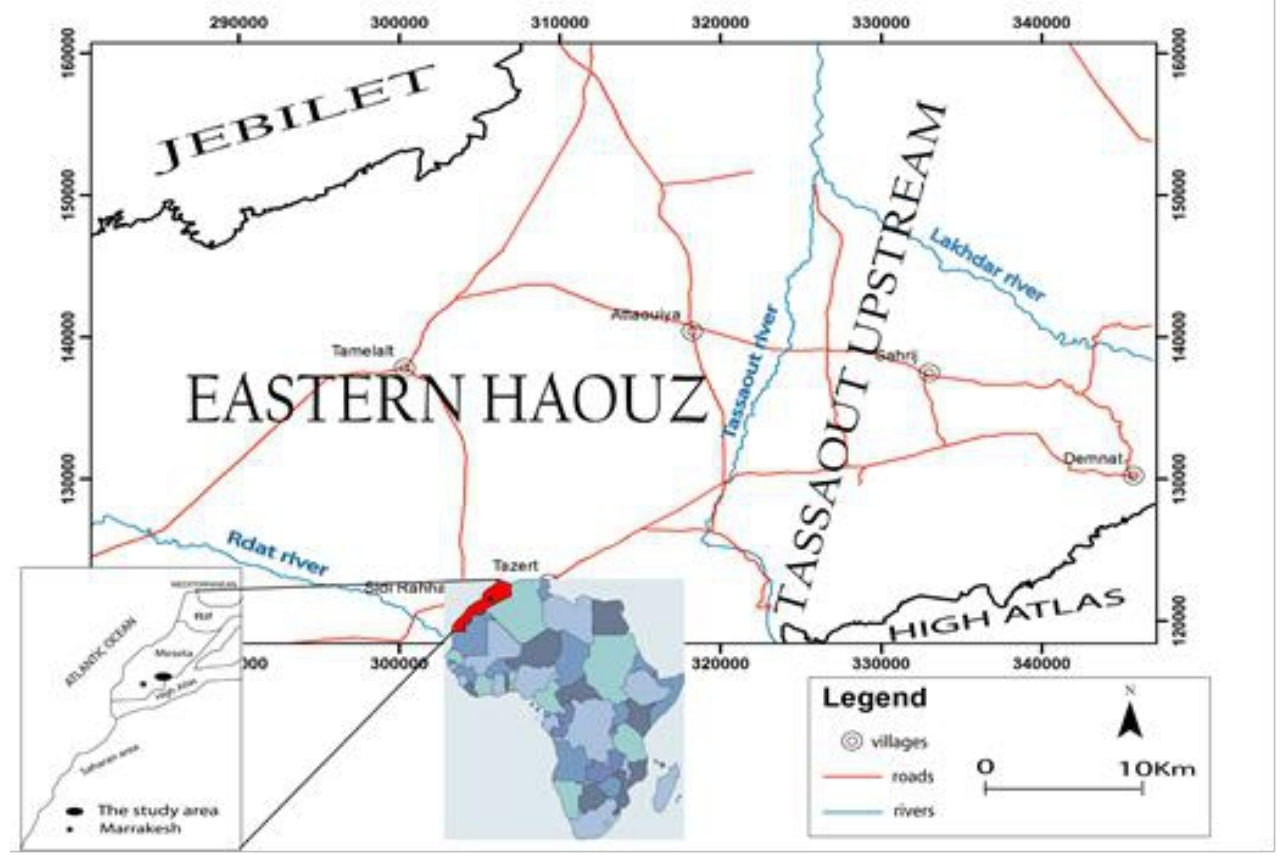

Figure 1. Overview of the study area

The altitudes of the study area vary from $466 \mathrm{~m}$ to $1588 \mathrm{~m}$ (Figure 2). In the central area, the altitudes are low (466 to 700 meters), and the slope values are also low $\left(<6^{\circ}\right)$. Thus, it corresponds to the quaternary sedimentary 
formations. In this area, the slopes are only locally higher in the margins of the main rivers. The higher altitudes and slopes (up to $60^{\circ}$ ) are located in the Hercynian Jebilet area in the north, with altitudes up to 1000-1200 meters, and High Atlas Mountains in the south, with altitudes up to 1488 meters.

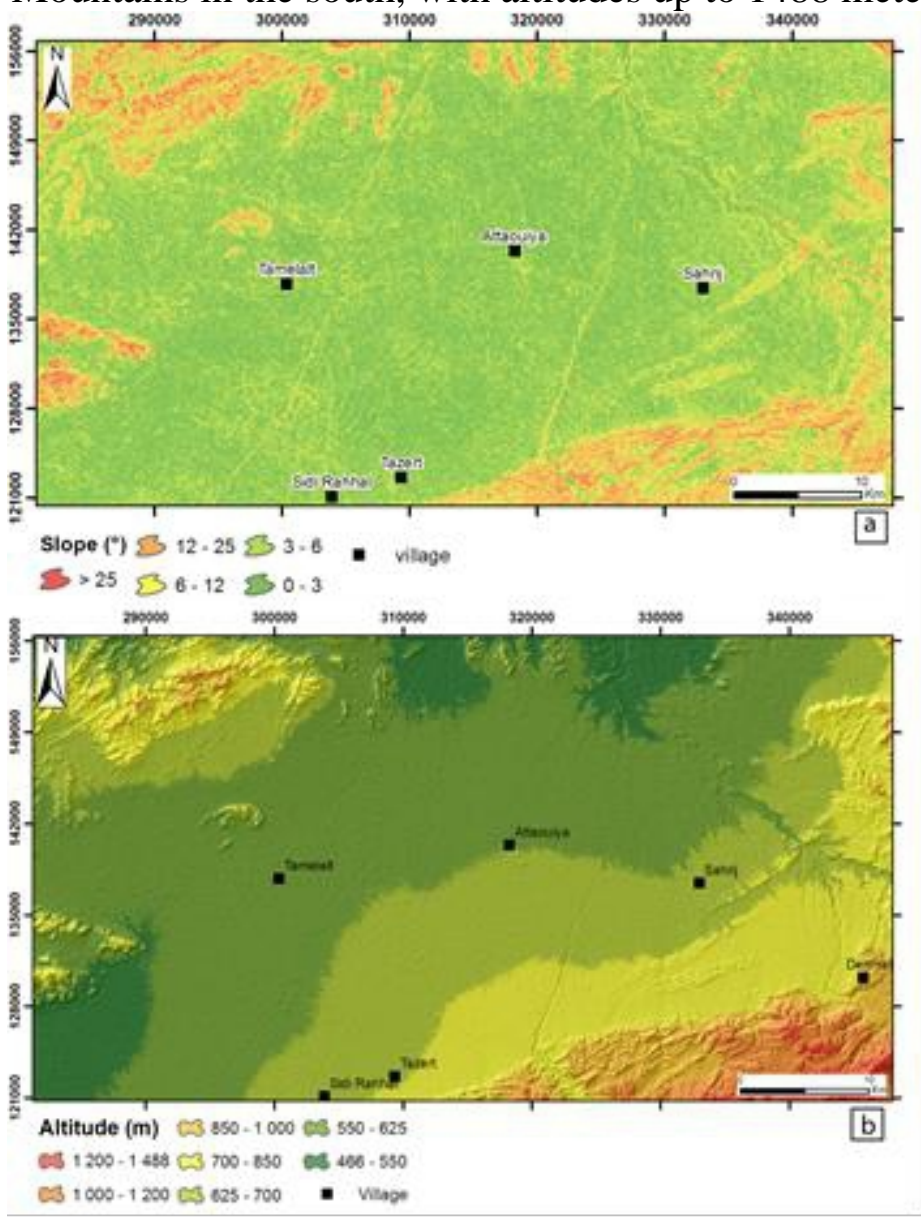

Figure 2. Slope map (a) and Hypsometric map (b)

Climate

The Haouz plain is characterized by a continental semi-arid climate with an average annual rainfall of about $415 \mathrm{~mm}$. It has a variation from 220 to $800 \mathrm{~mm}$ in different years (1973-74 to 2009-10, Figure 3) (year indicates September to August). The rainfall is distributed throughout the year, but most of the rainfall occurs during October to May, with a variation of 30-60 $\mathrm{mm} / \mathrm{month}$. The other 4 months (June to September) represent the dry period with rainfall of about $10 \mathrm{~mm} / \mathrm{month}$. Due to the high average temperatures (up to $39^{\circ} \mathrm{C}$ ) and high evaporation, in general, the area looks dry. 


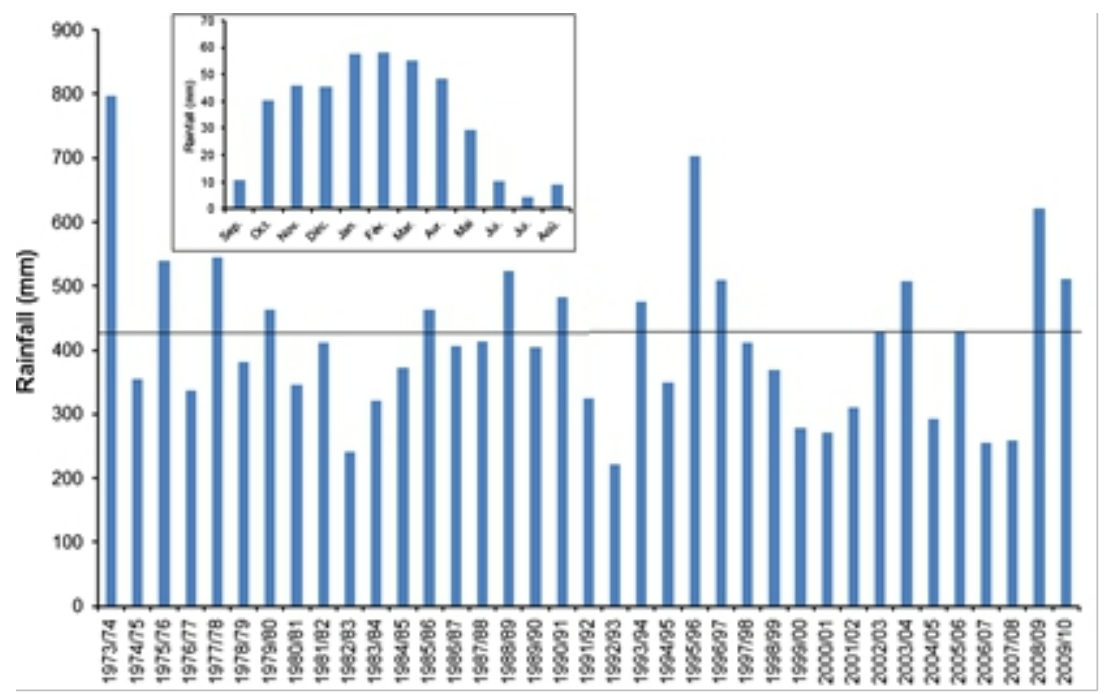

Figure 3. Annual rainfall distribution in the study area with an average of $415 \mathrm{~mm} / \mathrm{y}$, between $1973 / 74$ to $2009 / 10$. The inset shows average monthly distribution for the same period

\section{Geology}

The Haouz of Marrakesh is a basin of tectonic sedimentation whereby the Tertiary and the Quaternary have accumulated important detrital formations, resulting from the erosion of the High Atlas chain set up during the atlasic orogenesis (Ferrandini \& Le Marrec, 1982). The geological history of the Haouz basin was marked by the succession of several events, initiated in the Mesozoic, by the settlement of a Paleozoic basement freshly structured by the Hercynian orogeny (Ambroggi \& Thuille, 1952). Then, the plays of faults and flexures linked to tertiary tectonic movements led to the installation of an important pit between the High Atlas and the Jebilets. This has constituted an area of accumulation of recent sediments resulting from the erosion of the High Atlas chain during its uplift to the Oligo-Miocene and the Pliocene. These sediments consist mainly of alluvial deposits in the form of polygenic detrital deposits of continental or torrential type, which have drowned the main structural features of an ancient palaeorelief (El Goumi, 2010; Michard, 1976; Hoepffner, 1987).

Structurally, the history of the Haouz is characterized by the succession of several tectonic episodes generated mainly by the succession of the two hercynian and atlasic orogenic cycles (Soulaimani, 1991; Ouadjou, 1997):

- A Distensive Early Structuring of Target Age: It corresponds to a phase of opening of the basin materialized by a sedimentary and tectonic instability, with the development of faults with normal component being organized in hemigrabens to collapse East to South-East. 
- Synschist Compression: This is the major Hercynian tightening phase, marked at the Namuro-Wesphalien by a large compression responsible for a regional schistosity of general direction NNE-SSW.

- A Late-Hercynian Brittle Deformation Phase (El Goumi, 2010): This phase occurred in a non-metamorphic climate and is materialized by the reoccurrence of major $\mathrm{N} 70^{\circ} \mathrm{E}$ accidents, accompanied by folding structures.

After the Hercynian orogeny, the region was subjected to the atlasic tightening which in particular generated the uplift of the Paleozoic massifs of the Haouz of Marrakech. This tightening is mainly manifested by a brittle tectonics of medium direction ENE-WSW.

\section{Hydrogeology}

Hydrogeologically, the study area is formed by unconfined Quaternary and Mio-Pliocene aquifers and a deep confined Jurassic aquifer (Sinan, 2000; Moukhchane, 1983; Razoki, 2001). In the southern portion of the study area, recharge takes place in limestone outcrops of the Jurassic and Plio-Quaternary formations of the High Atlas Mountains (Rochdane, 2014). In the northern portion of the study area, groundwater recharge takes place from Paleozoic formations in the Jebilet Mountains (Rochdane, 2014). Within the plains, the recharge is driven by the direct infiltration of rainwater and flood waters from the rivers cutting across the plain, namely: the Lakhdar, Tassaout, and Rdat Rivers (Figure 1). Consequently, it is also driven by the return flow from irrigation water at the perimeter of the Tassaout River (Rochdane, 2013).

\section{Data and Methodology}

The numerical model has been achieved using the software GMS (Groundwater Modeling System) initially developed by "Environmental Modeling Research Laboratory of Brigham Young University" in collaboration with "U.S. Army Engineer Waterways Experiment Station" (GMS, 1999). Therefore, this is a graphic interface with different numerical codes that allows the understanding of a phenomenon by its explicit description.

A hundred of boreholes and deep wells, from the hydrological basin agency of Marrakesh and also several other wells analyzed in three geological recognition missions, were used for the realization of the two geological crosssections $\mathrm{C} 1$ and $\mathrm{C} 2$ (Figure 4 and Figure 5) and for the 3D representation. 


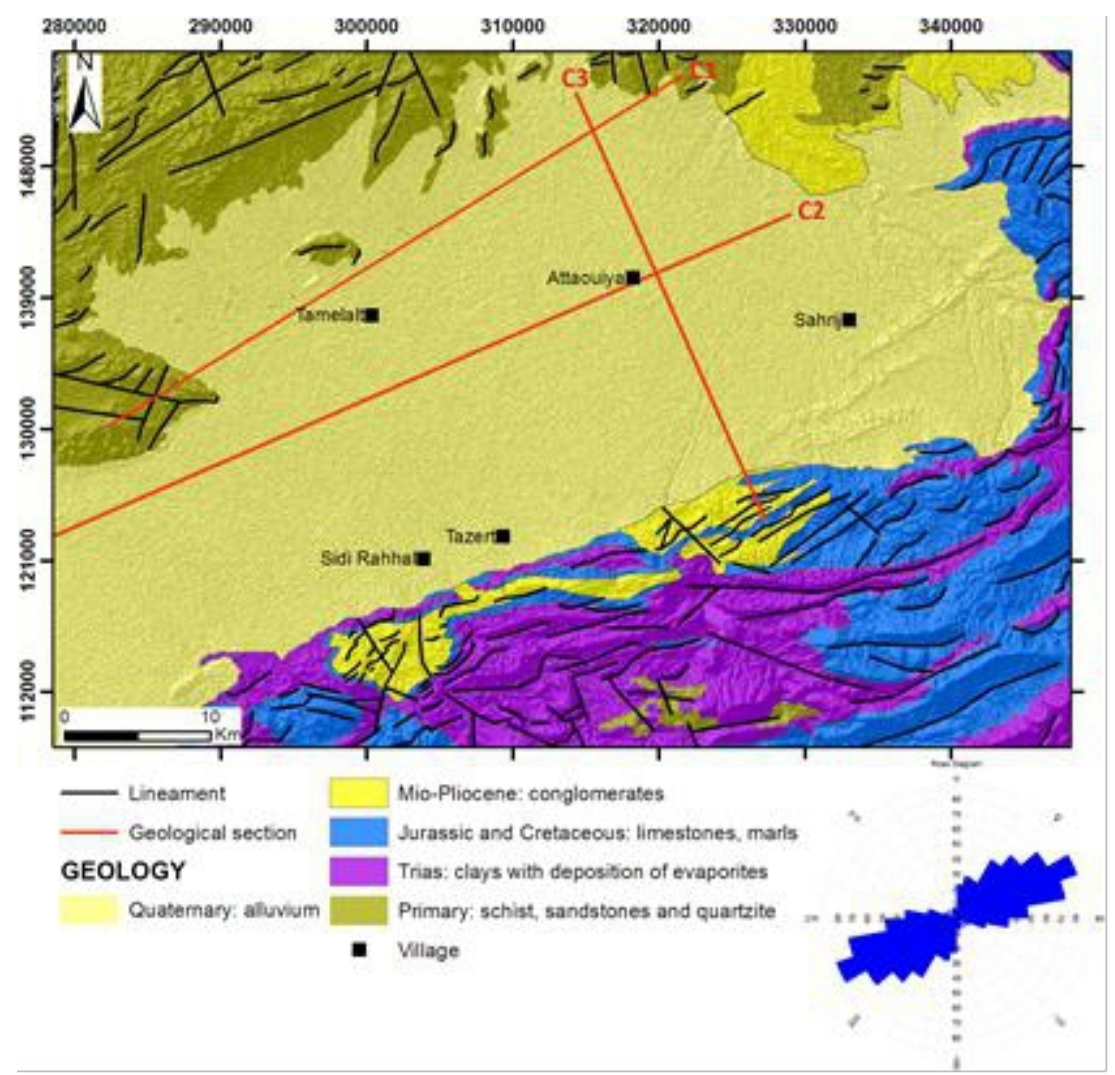

Figure 4. Geology (according to the 1:50 000 geological map of Morocco), photo interpreted tectonic lineaments map and location of geological sections $\mathrm{C} 1, \mathrm{C} 2$ and $\mathrm{C} 3$ 

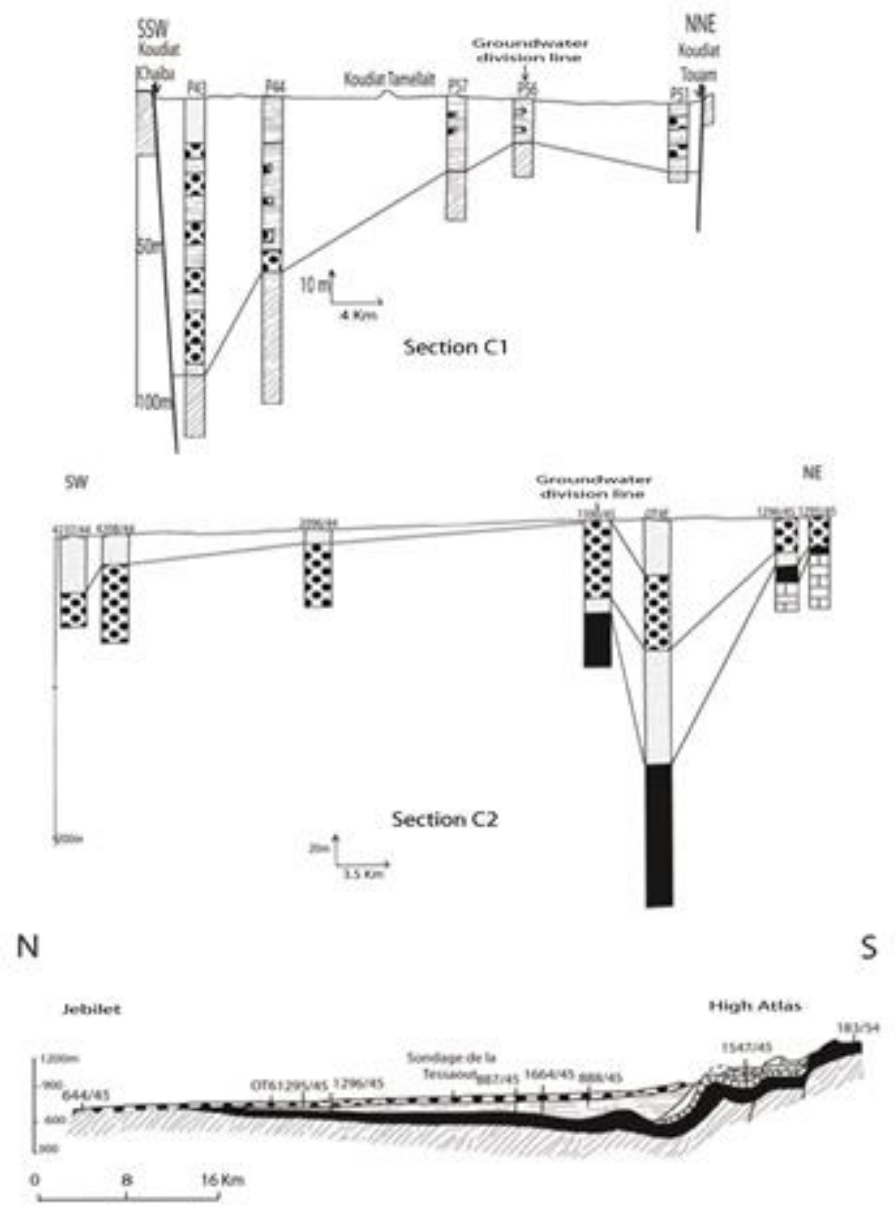

Section $C 3$ (Bernert and Prost 1975)

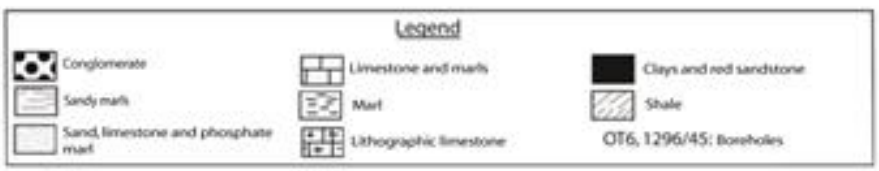

Figure 5. Geological sections C1, C2 and C3

The work was done in several stages (Figure 6). The data were entered into an Excel file with different characteristics, such as coordinates, geological formations, depths etc. Hence, it was subsequently introduced in GMS. 


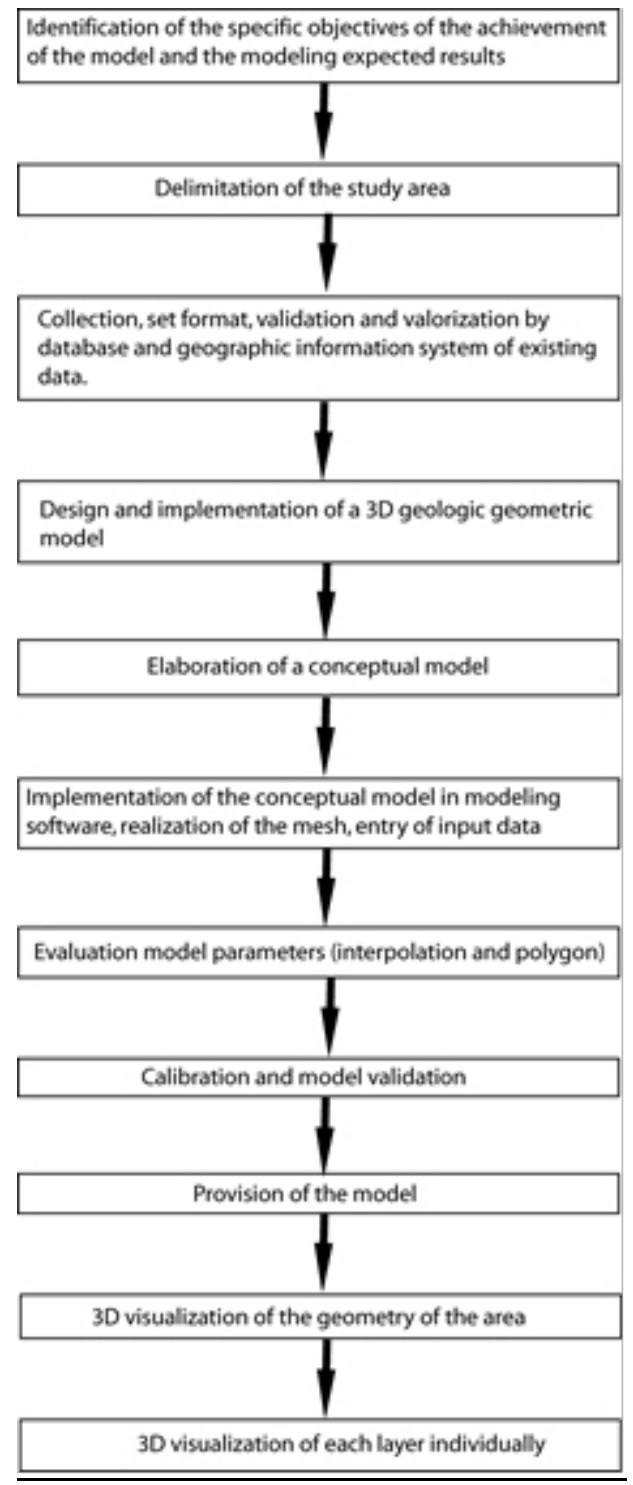

Figure 6. Scheme representing the methodologies used in this study

\section{Results and Discussion}

The analysis of structural and stratigraphic data correlated with the 1:50 000 geological map, boreholes, and deep wells was summarized by two geological sections (C1, C2) and the C3 of Bernert and Prost (1975) section (Figure 5). The Haouz basin has a synclinal form. It is divided into two well differentiated geological features, the primary basement on which recline uncomfortably the secondary, tertiary, and quaternary cover formations. The section $\mathrm{C} 3$ shows that the secondary and tertiary cover is limited to the High 
Atlas, and the Paleozoic basement is deep in the south of the plain, and becomes shallow in the north and outcrop at the Jebilets.

The five principal geological formations are shown in Figure 4. The basement formation comprises of a very thick series of schist belonging to Paleozoic era and is exposed in the north and north-western part of the study area. The Triassic formation comprises of deposits of clay, sandstone and evaporate layers, exposed in the southern side of the study area and overlain the Paleozoic formation. The Jurassic and Cretaceous formations consist of limestone and crops out only in the southern and eastern parts of the plains. The Mio-Pliocene formations consist of limestone or dolomites, alternating with sandstone layers exposed at certain locations in the northern and southern side of the plains. The Quaternary formation, which is formed by alluvial facies comprising sand, silt, gravel, cobbles and polymictic conglomerates, is spread over $75 \%$ of the study area in the central part. Thickness of this alluvium varies from 0 to $100 \mathrm{~m}$ and overlies the Mio-Pliocene formations.

The lineaments map (Figure 4) represents the set of unique segments resulting from the superposition of the information contained in a filtered satellite image and the digital terrain model. It contains 189 lineaments. Indeed, it reveals two important families of lineaments orientation: ENEWSW $\left(\mathrm{N} 70^{\circ} \mathrm{E}\right)$ and NNW-SSE $\left(\mathrm{N} 170^{\circ} \mathrm{E}\right)$. The ENE-WSW orientation is predominant. The lineaments have variable lengths ranging from hectometric to plurikilometric. Their distribution on the image is not homogeneous and is made in all directions.

The map shows a region with no lineament in the central zone of the map where there is the quaternary cover, a zone of medium density of lineaments. However, it is the northern zone and a zone of high density of lineaments in the south of the map. The rose diagram shows a dispersion of values, with a significant peak in the $\mathrm{N} 60^{\circ} \mathrm{E}-\mathrm{N} 70^{\circ} \mathrm{E}$ direction.

The piezometric map shows that the recharge of the aquifer takes place from two main zones (Figure 7). In the southern portion of the study area, recharge takes place in limestone outcrops of the Jurassic and Plio-Quaternary formations of the High Atlas Mountains. In the northern portion of the study area, groundwater recharge takes place from Paleozoic formations in the Jebilet Mountains. Within the plains, the recharge is driven by the direct infiltration of rainwater and flood waters from the rivers cutting across the plain, namely the Lakhdar, Tassaout, and Rdat Rivers (Figure 1). In addition, it is also driven by the return flow from irrigation water at the perimeter of the Tassaout River. The groundwater flow is imposed by a groundwater division line oriented NW-SE that gives two main directions of groundwater flow: N$\mathrm{S}$ and NE SW. The hydraulic gradient is low at the center of the map and becomes stronger at the two recharge areas. The outlet of the aquifer is located in two zones: the corridor of Tassoout and the central Haouz. 


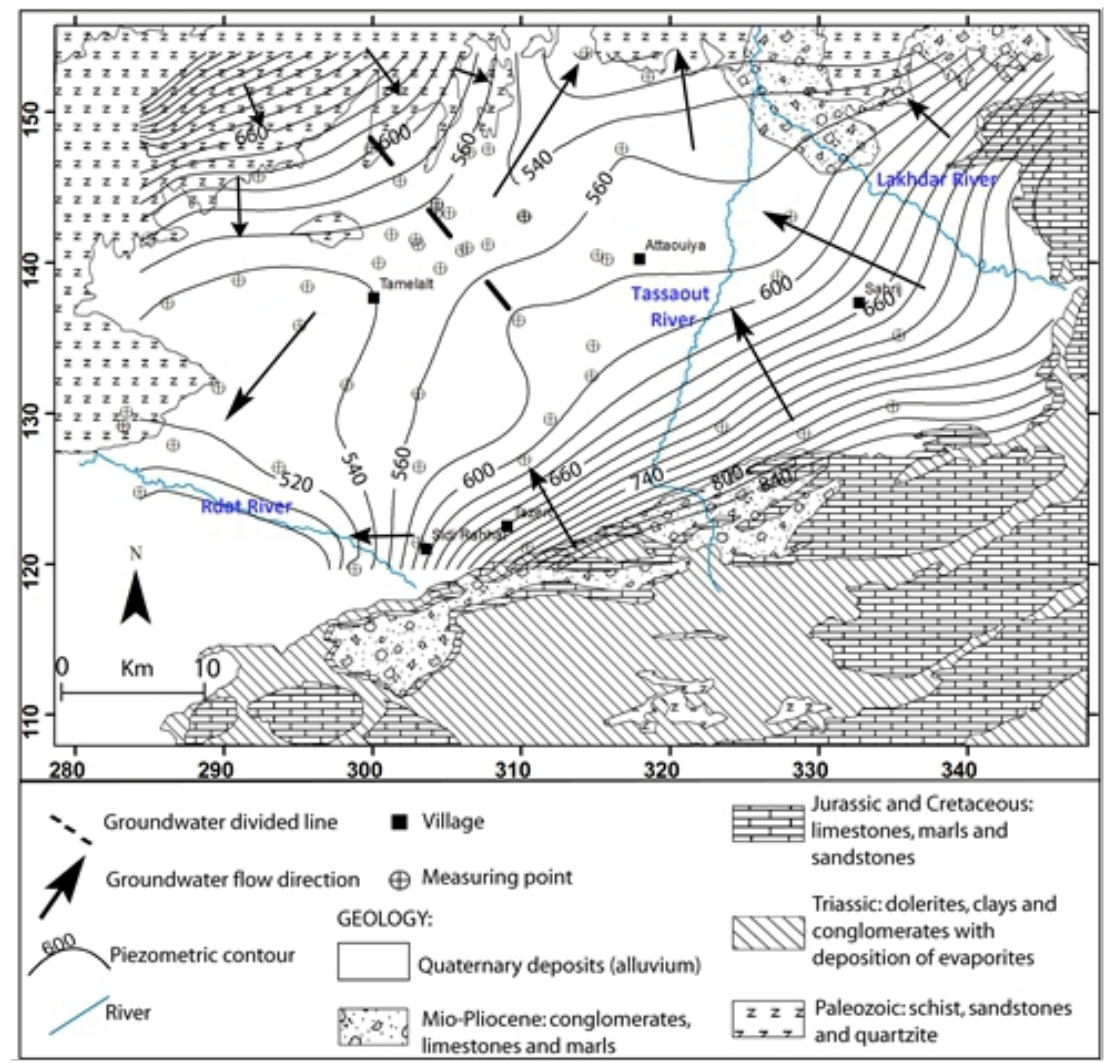

Figure 7. Geology of the study area (according to the 1:50 000 geological map of Morocco) and piezometric map.

The modeling results and the analysis of the Geological Map show the spatial distribution of the subsoil of the Eastern Haouz. The digital terrain model (DTM) map established from the data of the latitude, longitude, and altitude of the formations (Figure 8) shows the location of 103 wells and boreholes and the distribution of altitudes. On the map, we observe two highest areas, the Jebilet in the North West and the High Atlas in the South East, as well as areas of lower elevations forming two depressions in the North East and South West. 


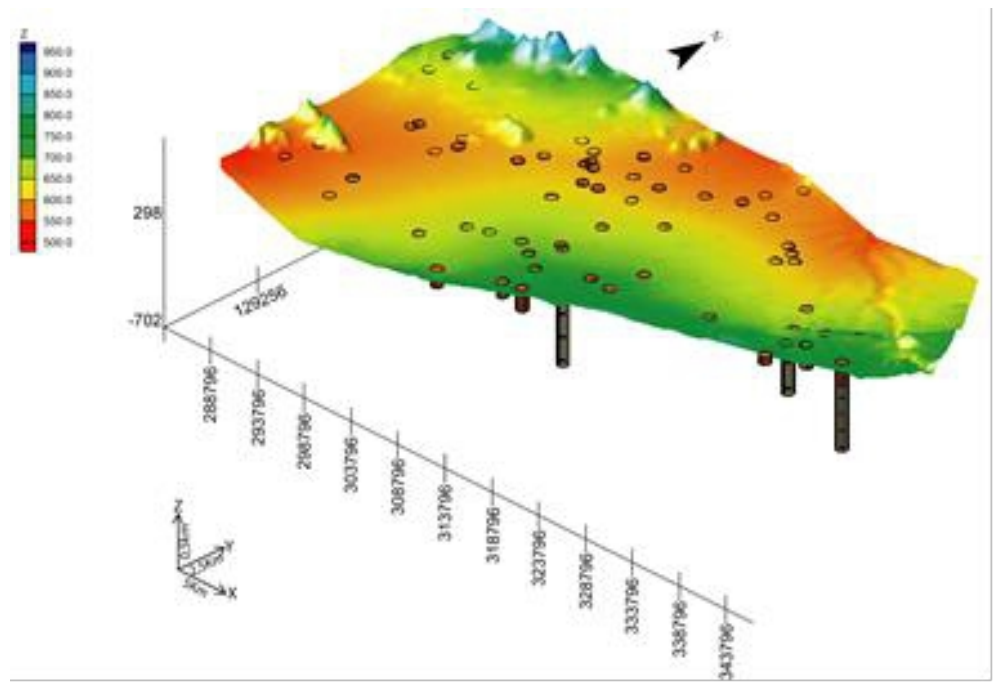

Figure 8. Digital Terrain Model and boreholes of the study area

To detail the spatial distribution of each part of the subsoil of the Eastern Haouz, two maps were made, a 3D modeling map of the basement and a 3D modeling map of the cover (Figure 9). The basement map (Figure 9 a) shows a rise in the north forming the Jebilets and a rise in the South and South East forming the High Atlas. The figure also shows a large basin in the North East with a significant dip of the basement to the East, and a small basin in the West with a slight dip of the basement to the West.

At the South of the plain, due to the significant depth of the basement, the drilling could not reach it. Hence, this shows blank.

Figure $9 \mathrm{~b}$ shows that the cover is spread over the whole plain, except the North West where there is outcrop of the basement. The cover is very well developed at the large basin in the North East, the small basin in the South West, and at the center.
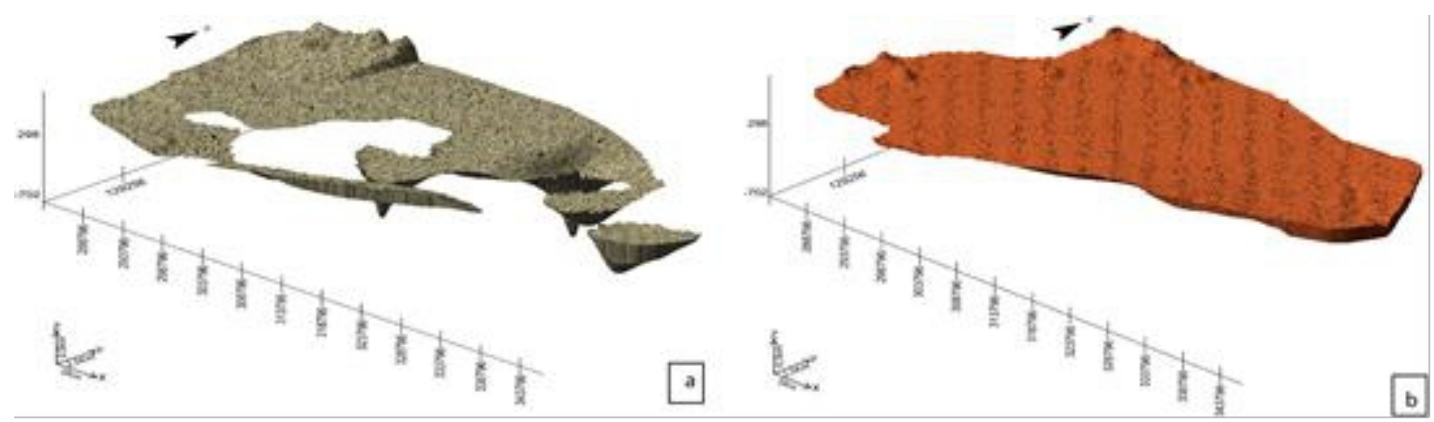

Figure 9. 3D modeling of the basement (a) and the cover (b) of the Eastern Haouz basin

The rise of the basement in the North and South and the presence of the two basins in the North East and West produce the groundwater division 
line that corresponds to the surface water divided line given by the piezometric map.

The final 3D modeling of the Eastern Haouz (Figure 10) shows that the cover matches the shape of the basement; and where there is the outcrop of the basement, coverage does not appear. The rise of the basement in the North and South and the presence of the two basins in the North East and the West, give the groundwater division line underlined by the piezometric map.

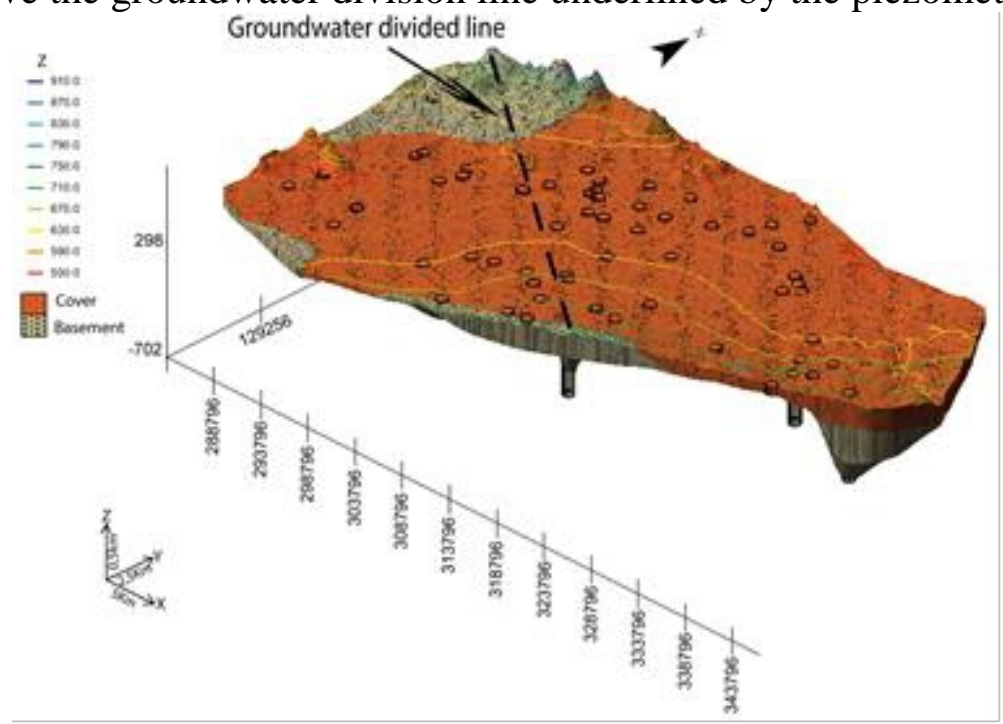

Figure 10. 3D modeling of the Eastern Haouz basin

\section{Conclusion}

Representation and analysis of geological architecture for specific applied research, such as groundwater modelling, are often simplistic approximations of real aquifer geometry. The compilation of drilling and geological data has allowed us to define the geological nature of the reservoir and the substratum, and also the geometry. The reservoir is a synclinal depression formed by Mio-Pliocene-Quaternary alluvium, limited at the bottom by schist and clay of the Paleozoic and the Triassic.

The geological sections show that the region is formed by a subsiding basin surrounded by two horsts corresponding to the Jebilets and the High Atlas. At the South of the plain, the important thickness of the cover gives a good accumulation of water and ensures the reservoir supply. The results of the 3D modeling, performed on 103 deep drilling, are consistent with the results of geological sections and the digital terrain model data (DTM). The results of the 3D representation shows the spatial distribution of the basement of the Eastern Haouz, where the cover follows the shape of the basement. The basement rises in the North and the cover is thick and developed at the two basins and at the center of the plain. The rise of the basement requires the axis 
of the anticline which corresponds to the groundwater division line. Both of the basins correspond to the accumulation of groundwater area.

\section{References:}

1. Ambroggi, R. \& Thuille, G. (1952). Haouz de Marrakech. Hydrogéologie du Maroc. Notes, Mém., Serv., Géol., Maroc, n 97.

2. Aug, C. (2004). Modélisation géologique 3D et caractérisation des incertitudes par la méthode du champ de potentiel. Dissertation, Ecole des mines de Paris, France.

3. Bernert, G. \& Prost, JP. (1972). Bilan de la nappe du Haouz, étude hydrodynamique en régime permanent, introduction générale. Rapp. inéd. MTPC/DH/DRE, J3.

4. Bouazza, M., Khattach, D., Houari, MR., \& Kaufmann, O. (2013). Apport du modèle géologique 3D à l'étude de la structure de l'aquifère profond d'Aïn Béni Mathar,Maroc Oriental. Bulletin de l'Institut Scientifique, Rabat(35): 53-61.

5. Cabello, P., Cuevas, JL., \& Ramos, E. (2007). 3D modelling of grain size distribution in Quaternary deltaic deposits (LlobregatDelta, NE Spain). GeologicaActa, 5(3), 231-244.

6. Carneiro, JF., Boughriba, M., Correia, A., Zarhloule, Y., Rimi, A., \& El Houadi, B. (2010). Evaluation of climate change effects in a coastal aquifer in Morocco using a density-dependent numerical model. Environmental Earth Sciences, 61(2): 241-252.

7. Chkara, I., Dollé, F., Jamin, P., Orban, P., Brouyère, S., \& El Morabiti, K. (2011). Modélisation du risque de pollution des eaux souterraines par des activités industrielles dans la plaine alluviale de la Meuse (Liège, Belgique), EuroMediterranean Scientific Congress on Engineering, Algeciras.

8. Daafi, Y., Chakir, A., Jourani, E., \& Ouabba, M. (2014). Geology and mine planning of phosphate deposits: Benguerir deposit Gantour Basin - Morocco. Procedia Engineering 83 ( 2014 ) 70 - 75. Elsevier.

9. Dessargues, A. (2000). Modélisation des réservoirs souterrains. Dissertation, Université de liège.

10. EL Anzi, R. (2007). Contribution à l'évaluation des occupations du sol par la méthode diachronique (cas des cinq communes limitrophes de la lagune de Nador). Dissertation, Salé, Maroc.

11. El Bouqdaoui, K., Aachib, M., Blaghen, M., \& Kholtei, S. (2009). Modélisation de la pollution par les nitrates de la nappe de Berrechid, au Maroc, Afrique Science 05(1) (2009) 99 - 113.

12. El Goumi, N., Jaffal, M., Kchikach, A., \& Manar, A. (2010). Apport de la gravimétrie à l'étude de la structure du bassin du Haouz (Maroc). Estudios Geologicos (2010). 1-11. 
13. El Yaouti, F., El Mandour, A., Khattach, D., Benavente, J., \& Kaufmann, O. (2009). Salinization processes in the unconfined aquifer of Bou-Areg (NE Morocco): Ageostatistical, geochemical, and tomographic study. Applied Geochemistry, 24(1): 16-31.

14. Ferrandini, J. \& Le Marrec, A. (1982). La couverture jurassique à paléogène du Haut Atlas de Marrakech est allochtone dans la « zone des cuvettes »d'Aït Ourir (Maroc). Comptes Rendus de l'Académie des Sciences, 295, II : 813-816.

15. Frind, EO., Muhammad, DS., \& Molson, JW. (2002). Delineation of three dimensional well capture zones for complex multiaquifer systems. Ground Water, 40(6), 586-598.

16. Gallerini, G. \& De Donatis, M. (2009). 3D modeling using geognostic data: The case of the low valley of Foglia river (Italy). Computers \&Geosciences, 35(1): 146-164.

17. Gámez, D. (2007). Sequence stratigraphy as a tool for water resources management in alluvial coastal aquifers: application to the Llobregat delta (Barcelona, Spain). Dissertation, Technical University of Catalonia, Barcelona, Spain.

18. GMS - Environmental Modeling Research Laboratory (1999). « Groundwater Modeling System - GMS Reference Manual », Birmingham Young University, Birmingham.

19. Hoepffner, C. (1987). La tectonique hercynienne dans l'est du Maroc. Dissertation, University of Strasbourg.

20. Jiménez-Martínez, J., Aravena, R., \& Candela, L. (2011). The role of leaky boreholes on the contamination of a regional confined aquifer: A case study in the Campo de Cartagena region, Spain. Water, Air \&Soil Pollution, 215, 311-327.

21. Kaufmann, O. \& Martin, T. (2008). 3D geological modelling from boreholes, cross-sectionsand geological maps, application over former natural gas storages in coal mines. Computers \& Geosciences, 34(3): 278-290.

22. Mathers, S., Burke, H., Terrington, R., Thor, S., Dearden, R., Williamson, J., \& Ford, J. (2014). A geological model of London and the Thames Valley, southeast England. Proceedings of the Geologists' Association, 125(4): 373-382.

23. Michard, A. (1976). Eléments de géologie marocaine. Notes et Mém. Serv. Géol. Maroc, 252, 408.

24. Moukhchane, M. (1983). Contribution à l'étude des réservoirs profonds de la bordure nord de l'Atlas entre Demnat et Imin'tanout (Maroc). Dissertation, Besançon. 
25. Ouadjou, A. (1997). Pétrographie, géochimie et structure des roches magmatiques ante-schisteuses des massifs hercyniens des Guemassa et Souktana. Dissertation, Université de Marrakech, Morocco.

26. Razoki, B. (2001). Mise en place d'un système de gestion de base de données pour la gestion des ressources en eaux souterraines de la plaine du Haouz (Meseta Occidentale, Maroc). Dissertation, Faculté des sciences Semlalia de Marrakech, Maroc.

27. Rochdane, S., El Mandour, A., Jaffal, M., Himi, M., Casas, A., Amrhar, M., \& Karroum, M. (2014). Géométrie de l'aquifère du Haouz oriental et Tassaout amont. Maroc occidental: Approche géophysique et hydrogéologique. Hydrological Sciences Journal DOI: 10.1080/02626667.2014.979174.

28. Rochdane, S., Reddy, DV., \& El Mandour, A. (2014). Hydrochemical and isotopic characterisation of Eastern Haouz plain groundwater, Morocco. Environmental Earth Sciences - Springer. ISSN 1866-6280. DOI 10.1007/s12665-014-3633-7.

29. Rochdane, S., El Mandour, A., Jaffal, M., Himi, M., \& Casas, A. (2013). The quality of surface and ground water in the eastern Haouz and Tassaout area, Morocco Hydrological Sciences Journal: red book for the Symposia H04: "Understanding fresh-water quality problems in a changing world", (IAHS Publ. 361, 2013) ISBN Number: 978-1907161-39-1. Pp 220-226.

30. Rziki, S., Alansari, A., Mouguina, EM., Simard, J., Zouhair, M., \& Maacha, L. (2012). Apport du modèle géologique et géophysique 3D dans le développement du gisement polymétallique de Draa Sfar (Massif hercynien des Jebilet centrales, Maroc), Estudios Geológicos, 68(1) enero-junio 2012, 29-40.

31. Sinan, M. (2000). Méthodologie d'identification, d'évaluation et de protection des ressources en eau des aquifères régionaux par la combinaison des SIG, de la géophysique et de la géostatistique : Application à l'aquifère du Haouz de Marrakech (Maroc). Dissertation, Université Mohammed V, Ecole Mohammadia d'Ingénieurs.

32. Soulaimani, A. (1991). L'évolution structurale des massifs hercyniens du Haouz de Marrakech : Guemassa- N'fis (Maroc). Dissertation, Uni. Cadi Ayyad, Marrakech, Maroc.

33. Wang, G., Li, R., Carranza, EJM., Zhang, S., Yan, C., Zhu, Y., Qu, J., Hong, D., Song, Y., Han, J., Ma, Z., Zhang, H., \& Yang, F. (2015). 3D geological modeling for prediction of subsurface Mo targets in the Luanchuan district, China. Ore Geology Reviews, 71:592-610. 